\title{
Technological aspects of GEOSECMA for ArcGIS and EPANET integration - case study
}

\author{
Maciej Kalinowski ${ }^{1, *}$, Daniel Grzelak ${ }^{1}$ \\ ${ }^{1}$ Przedsiębiorstwo Wodociągów i Kanalizacji w Ząbkach Sp. z o.o., 2 Piłsudskiego Str, 05-091 Ząbki, \\ Poland
}

\begin{abstract}
In general, GEOSECMA for GIS (GfA) and the EPANET hydraulic model are complementary tools from a technological, financial and operational point of view. It is in this way, that water companies can reduce substantial time and money, and provide extensive capability to support decisions in the planning, operation, management and the expansion of water distribution systems. This paper is an attempt to formulate technological assumptions and methodology for GfA-EPANET integration using the example of the water distribution network serving Ząbki, a medium-sized city in the Warsaw metropolitan area. This integration is understood as the process of the spatial physical and water demand data exchange between GfA and the water distribution hydraulic model with a structure tailored to the needs of water meter reading systems.
\end{abstract}

\section{Introduction}

Integration of GIS-GEOSECMA for ArcGIS (GfA) offered by ESRI Polska and the hydraulic model (HM) EPANET is the process by which updated properties of water distribution network (WDN) elements are synchronized and migrated between the geodatabase (GDB) and the hydraulic model (HM). Basically, GIS and hydraulic models are complementary technology and when integrated can provide tremendous operational benefits [1-3]. Therefore, integration philosophy has been increasing in popularity [1-8] and more than $80 \%$ of all information used by a water utility is geographically referenced [9]. GfA is rather oriented to a "what" and "where" option. The GfA applications provide not only mapping but offer extensive tools for spatial analysis and data management. This has resulted in a more accurate hydraulic model because of demand and distribution network fidelity [10]. GfA, on the other hand, does not provide hydraulic data which are necessary for efficient water management.

The EPANET model if calibrated, bridges this gap by simulating numerically hydraulic efficiency and the capacity of WDN.

Hydraulic models are predictive by definition and to a great extent concern "what if" scenarios.

*Corresponding author: maciej.kalinowski@pwikzabki.pl 
Throughout the integrated approach, hydraulic model updates occur much more frequently, because the time consumption for input data transfer to EPANET can be greatly reduced.

The general objective for which the integration model was built is the practical use of a reliable, updated model as a decision support tool in planning, operating and management (O\&M) in the PWiK daily and long range operation tasks.

It was assumed that the preconditions for achieving the general objective are to:

- provide a GfA - EPANET integration procedure which takes into account all GDB elements required by EPANET, including existing WMR and planned SAMR water meters reading systems,

- shorten the time for the building of network geometry in order to increase EPANET input up-dating frequency,

- improve O\&M staff preparedness and response by providing hydraulic data prediction such as water pressure at junctions and delivery points, unit loss of pressure, water age, hourly based flow etc. and relate them to the background map layers,

- update the EPANET model periodically according to updated GfA data,

- use the updated EPANET model for the daily and long range decision and planning process,

- allow access to georeferencing the WDN components with absolute coordinates, relating them to the background map layers such as buildings, streets and plots,

- enable access to all attributes of the water distribution network, including water meters,

- categorization and balance of water demands and allocating them by using the spatial capabilities offered by GfA.

\section{Study area}

Ząbki, is a medium-sized town in the Warsaw metropolitan area populated by approximately 30000 inhabitants, with the population projected to increase to about 50000 persons in the target time horizon.

Nowadays, the city is supplied from two basic water sources: the newly developed water treatment plant with a daily average capacity of $3000 \mathrm{~m}^{3} / \mathrm{d}$, and two water mains from Warsaw's water network.

Walk-by remote water meter reading systems (WMR) that are based on a new generation IZAR RC I radio module comprised of a portable PSION PRT terminal, an IZAR PRT Bluetooth receiver, an IRDA optical sensor and IZAR radio modules have been installed and are operational at the PWIK Ząbki. Recently, a Stationary Automatic Meter Reading (SAMR) system has been designed to replace the existing house-to-house meter readers.

The current network is composed of 8000 junctions and 7800 pipe sections. About $52 \%$ of the pipe lengths have diameters of $110 \mathrm{~mm}$, while they can range from $40 \mathrm{~mm}$ to 350 $\mathrm{mm}$ in diameters. As much as $86 \%$ of the distribution pipes are made of PEHD. WDN covers a total of 3000 service connection pipes, which supplies 3300 contract customers. More than $99 \%$ of the total water consumed is metered.

\section{Integration procedure}

The proposed integration process, comprising the set of tasks set out in logical sequence are demonstrated graphically on Figure 1. 


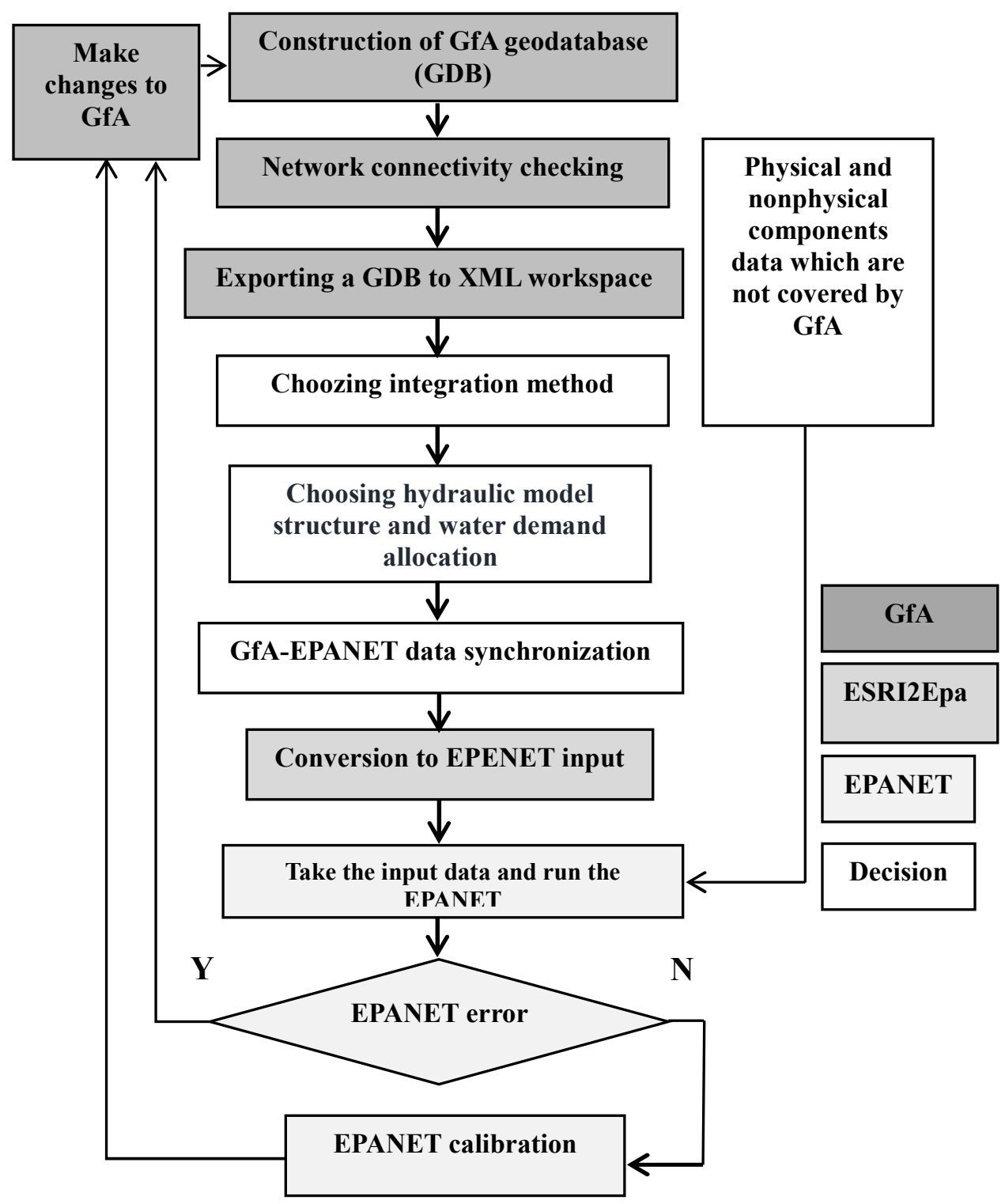

Fig. 1. Integration procedure assumed for WDS Ząbki.

The detailed explanations of each step are listed below:

Construction of the GfA geodatabase $\rightarrow$ The GDB represents geographic features and all WDN attributes, and is hosted inside a relational database management systems. Vector and raster maps from WDS was imported from District Centre Geodetic and Cartographic Documentation and digitized again.

Network connectivity check $\rightarrow$ Topological errors occur when the network elements are not connected as specified. For networks, a common error is when linear features that 
should be connected are disjoined due to bad digitization. The series of advanced editing tools were grouped in different GfA tool bars. After topology rules had been established and validated, validation errors were analyzed using topology review tools in GfA, and connectivity errors such as overlapping or orphan pipes have been identified and corrected.

Choosing integration method $\rightarrow$ Taking into consideration accessibility and affordability, the following GfA-EPANET integration methods has been considered [13, 14]: a) method based on Graphical User Interface (GUI), b) method based on EPANET's Programmer's Toolkit, c) method which uses source code for the EPANET Pipe Network Analysis system. From a practical point of view, the shortcoming of the last two methods is the need for a very advanced and detailed knowledge of computer programming, as well as algorithmization and numerical solutions for mathematical equations describing WDS, which is beyond of our capability at the moment. Therefore, the first integration method is recommended i.e. based on Graphical User Interface.

Choosing hydraulic model structure $\rightarrow$ Before the start of data conversion from GfA to the hydraulic model, it is necessary for the modeler to select the level of HM detail by choosing the hydraulic model structure to be compiled with the existing WDN and water company plans regarding WDN modernization and refurbishment. In the case of PWiK, an APV hydraulic data structure is preferred since the company has a plan to replace the existing house-to-house water meter system with a more advanced Stationary Automatic Meter Reading system (SAMR,) designed for the real-time collection of readings. It is also important to make sure that the modeling elements match the corresponding features in the GfA. A qualitative comparison between the typical hydraulic model structures based on various comparison criteria (Table 1) confirm the advantages of the APV model applied to the Zabki WDN.

Table 1. Comparison between various hydraulic models structures on the basis of [1].

\begin{tabular}{|c|c|c|c|c|}
\hline \multirow[t]{2}{*}{ Comparison criteria } & 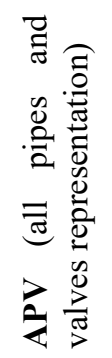 & 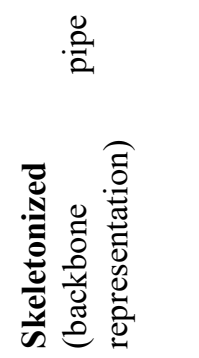 & 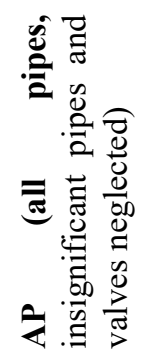 & 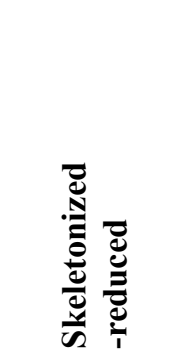 \\
\hline & \multicolumn{4}{|c|}{ Assessments } \\
\hline $\begin{array}{ll}\text { Initial distribution } & \text { system } \\
\text { evaluation (IDSE) } & \\
\end{array}$ & Best & Maybe & Good & Maybe \\
\hline Fire flow & Best & Limited & Good & Limited \\
\hline Water quality & Best & Limited & Good & Limited \\
\hline Potential services & Good & Limited & Good & Limited \\
\hline Ease of GIS integration & Best & Good & Good & Limited \\
\hline Processing & Slow & Faster & Faster & Fastest \\
\hline Disk space & Large & Variable & Small & Smallest \\
\hline Maintenance & Easy & Easy & Difficult & Difficult \\
\hline Model accuracy & Good & Limited & Good & Limited \\
\hline Interoperability with (SAMR) & Good & Not possible & Good & Not possible \\
\hline
\end{tabular}


Choosing water demand allocation $\rightarrow$ It is common practice that mathematical modeling makes use of demand simplifications in order to reduce both the model size and processing time. One such popular simplification is the assumption that the consumptions of water are equally allocated from the beginning to the end of the pipe section, or in other words, that the total demand along the pipe is represented as two lumped withdrawals at its terminal nodes [16]. That assumes grouping of the consumptions associated with the line in one or both ends of the line and produces head loss errors which may be significant [17-18]. Therefore, an optimal solution regarding the demand spatial allocation would have been to consider each service connection pipe as a separate link and nodes in the model [18]. Fortunately, in the case of WDN Ząbki, almost $100 \%$ of the volume of consumed water has been measured by water meters (WM) installed at the service connections. It created the opportunity to allocate demand directly to the water meter readings being represented by nodes at the ends of service pipes. Demand data was entered manually by entering values from the customer database. A careful analysis has shown that the existing house-to-house water meter reading system is invulnerable to automatization. Therefore, water demand allocation has been made by Export/ Import data processing.

EPANET data synchronization $\rightarrow$ The GfA-EPANET integration requires some specific adaptations made in the GDB. This is due to several reasons. For example, the topological relationships used in modeling WDN are not the same as those needed by EPANET. As valves and pumps are modeled as nodes in GfA, they should be modeled as links for EPANET.

EPANET errors massages $\rightarrow$ During the testing calculations, EPANET returned error messages which had not been identified and previously corrected by the GfA network connectivity check toolbars. For example, error messages no. 110,203,204. These errors were amended in the model and reported back to the GfA system (Fig. 1).

Changes caused by model calibration $\rightarrow$ The model may also need to be updated by nonGfA based information during the model calibration phase and the corresponding changes would then need to be made in the GfA [12].

\section{Assumptions for data conversion}

There are several key requirements and considerations for the development of GfA centric hydraulic models recommended by the Environmental Systems Research Institute [10] and applied to the Ząbki WDS by the authors of this paper, and which is summarized in Table 2.

Table 2. GfA-EPANET integration assumptions [10].

\begin{tabular}{|c|l|}
\hline Element & Key principles \\
\hline \multirow{5}{*}{ Junctions } & Each junction feature in GfA has a unique ID and subtype \\
\cline { 2 - 3 } & $\begin{array}{l}\text { Represent hydrants and nonoperational fittings } \\
\text { Do not include non-control valves in the hydraulic model if they are represented as } \\
\text { point features in a geometric network }\end{array}$ \\
\cline { 2 - 3 } & Maintain elevations in the GfA \\
\cline { 2 - 3 } & Model related attributes should be maintained in the GfA base \\
\cline { 2 - 3 } Pipes & Correct orphan nodes as needed \\
\hline & $\begin{array}{l}\text { Each pipe feature in GfA has a unique ID and subtype (distribution, service } \\
\text { laterals, hydrants laterals) }\end{array}$ \\
\cline { 2 - 3 } & $\begin{array}{l}\text { Populate nominal and internal diameter, length, material and other model attributes } \\
\text { in GfA database }\end{array}$ \\
\cline { 2 - 3 } & Maintain FROM_NODE and TO_NODE pipe attributes in GfA database \\
\hline
\end{tabular}




\begin{tabular}{|l|l|}
\multirow{4}{*}{ Valves } & $\begin{array}{l}\text { Break pipe sections only at junctions (at mainline endpoints, tees, crosses) and } \\
\text { structures to be imported into the model }\end{array}$ \\
\cline { 2 - 3 } & Review and correct topology and connectivity as need \\
\hline \multirow{4}{*}{ Pumps } & Each valve feature in the GfA database has a unique ID \\
\cline { 2 - 3 } & Control valve structures should be represented in GfA as in the hydraulic model \\
\cline { 2 - 3 } & Maintain elevations in the GfA \\
\cline { 2 - 3 } & Ensure that each pump has a unique ID in the GfA database \\
\cline { 2 - 3 } & $\begin{array}{l}\text { Consider using SCADA system as a reference for control information } \\
\text { hydraulic model }\end{array}$ \\
\cline { 2 - 3 } & $\begin{array}{l}\text { Accurately identify pumps using pump curves from the manufacturers or pump } \\
\text { tests }\end{array}$ \\
\cline { 2 - 3 } & Maintain elevations of pump centerline in the GfA \\
\hline \multirow{3}{*}{ Water } & Ensure that each water meter has a unique ID in the GfA database \\
\cline { 2 - 3 } & Maintain elevations \\
\cline { 2 - 3 } & Provide the address of end users for each water meter in the GfA database \\
\cline { 2 - 3 } & Maintain elevations in GfA \\
\hline
\end{tabular}

The representative GfA features in EPANET are summarized in Table 3.

Table 3. Representative GfA feature in EPANET.

\begin{tabular}{|l|l|l|l|}
\hline GfA & Type & FPANET \\
\hline Feature class & Peature class & Type \\
\hline Hydrants and non-control valves & Point & Start and end junctions & Point \\
\hline Control and boundary valves & Point & Valves & Point or line \\
\hline Pumps & Point & Pumps & Point or line \\
\hline Pipes & Line & Pipes & Lines \\
\hline Tanks and reservoirs & Point & Tanks and reservoirs & Point \\
\hline Water meters & Point & Junctions & Point \\
\hline
\end{tabular}

\section{Integration model applied}

Basically, the integration model is based on the abovementioned procedure and assumptions and is comprised of the following programs which are related throughout data exchange and workflows:GfA,ESRI2Epa and EPANET. GfA is the program which provides all the WDN geometry and attributes and exports GDB to an XML workspace document. ESRI2Epa takes the XML documents, extracts the data relevant to build EPANET and convert it into an input file for EPANET. Then EPANET, supplemented by additional input data such as tank volumes, pumps characteristics, base demands, runs the hydraulic calculations of the selected WDN scenario for model testing. Normally, integration starts with the creation of GEOSECMA for the ArcGIS (GfA) database which serves as the repository for asset information and network connectivity.

GfA is a GIS-based solution for the support of managing water and sewage networks within municipal companies. It is based on the ArcGIS platform manufactured and maintained by Esri Inc. - the world's leading GIS company (according to to ARC Advisory Group- $42 \%$ market share). GfA may offer many advantages. The system catalogs the data within the specially designed structure, differentiating between not only the water and sewage networks, but also among all the elements of different types. Any GIS system stores the data for points, lines and polygons separately. In the case of GfA, the main pipes, junctions, valves, hydrants or joints are all in different layers. It is specially designed for cataloguing, managing, planning and conserving water and sewage networks, as well as distributing data and maps throughout the whole company. The data is accessible on 
desktops, through web browsers and mobile devices in the field. The most frequently used analyses are finding the valves to be closed in the case of an incident, generating network profiles, determining flow direction, detecting counter-flows, defining catchment areas and creating reports. The system also allows maintaining the inventory of incidents and conservation works.

Exporting a WDS geodatabase to an XML workspace document is the intermediate phase of data exchange between GfA and EPANET. The XML workspace document is an XML specification for the geodatabase that can be used to retain all geodatabase contents. All feature classes, tables, or relationships have been copied for the purpose of GfAEPANET integration. Instruction on how to exporting geodatabase using XML is clearly presented in the ArcGIS help [16].

ESRI2Epa [17] is the program that takes the abovementioned XML workspace document and converts it into a consistent model input file for EPANET. The program enables the reading of basic layers: Pipe Water Pipe i.e. water network geometry, Pipe Water Service Pipes i.e. water meters and service connection pipes, Pipe Water Hydrant i.e. hydrant location.

Another important ESRI2Epa feature is the conversion of multi segment pipes into a set of single segment pipes connected by nodes. This option appeared very practical since the pipes digitalization was elaborated and stored in GDB as multi segment pipes.

EPANET 2 is a public-domain software developed by the US EPA to numerically simulate hydraulic and water quality in a pressurized WDN [18]. In general, hydraulic modeling by using EPANET requires a set of data describing the physical and non-physical components [18].

\section{Summary}

- Procedure of GEOSECMA for ArcGIS and EPANET integration and assumptions for data conversion has been elaborated and satisfactorily applied for the Ząbki WDN.

- Two methods for the identification and correction of topological errors have been applied for models integration; one automatically at the GfA level; and the second manually at the level of EPANET.

- Comparative analysis of the different hydraulic structures resulted in the selection of the APV hydraulic structure which matches the requirements of both the existing and planned water reading system in the town of Zabki.

- It is expected that the water demands which were allocated at the service connection end nodes and representative of individual water meters, will significantly improve the O\&M of the Ząbki WDN.

- The operational hydraulic model for the town of Zabki is progressively being developed and will have an important role in the planning and management of the municipal WDS.

\section{References}

1. L.Armstrong, J.Edwards, E.Kowal, B.Lendt, P.Ginther, A.Black, L.C.Larsen, P.Hauffen, Benefits of integrating GIS and hydraulic modeling, Hydraulic modeling and GIS, 1, 3 (2012)

2. N.C.Gama, E.A. Lanfranchi, Q.Pan and A.Janoski, Water distribution network model building, case study: Milano, Italy, $13^{\text {th }}$ International conference on Computing and Control for the Water Industry, Procedia Engineering 119 (2015) 
3. C.Abdelbaki, M.M.Benchaib, S.Benziada, H.Mahmoundi, M.Goosen, Manage-ment of a water distribution network by coupling GIS and hydraulic modeling: a case study of Chetouane in Algeria, Application Water Science, 7 (2017)

4. A.R.Ayad, Geographic Information Systems in Water Distribution Networks, International Perspective on water resources \& the environment, 5 (January 2012)

5. R.Brodziak, J.Bylka, A.Urbaniak, Modele integracji narzędzi informatycznych $\quad \mathrm{z}$ programem EPANET, Eksploatacja wodociagów $i$ kanalizacji - GIS modelowanie $i$ monitoring $w$ zarządzaniu systemami wodociagowymi i kanalizacyjnymi, PZiTS/ Zakład Zaopatrzenia w Wodę i Odprowadzania Ścieków Politechniki Warszawskiej, Materiały Konferencyjne, (Kwiecień 2017)

6. A.Domasat, M.Jędrychowicz, Model hydrauliczny sieci wodociągowej w mieście Skierniewice, Eksploatacja wodociagów i kanalizacji-GIS modelowanie i moni-toring $w$ zarządzaniu systemami wodociagowymi $i$ kanalizacyjnymi, PZiTS/ Zakład Zaopatrzenia w Wodę i Odprowadzania Ścieków Politechniki Warszawskiej, Materiały Konferencyjne, (Kwiecień 2017)

7. B.Kowalska, D.Kowalski, P.Suchorab, K.Miszta-Kruk, N.Wronowski, Automa-tyczna konwersja danych przy budowie modeli numerycznych sieci wodociągowej i kanalizacyjnej - studium przypadku, Eksploatacja wodociagów i kanalizacji - GIS modelowanie i monitoring $w$ zarządzaniu systemami wodociagowymi i kanalizacyjnymi, PZiTS/Zakład Zaopatrzenia w Wodę i Odprowadzania Ścieków Politechniki Warszawskiej, Materiały Konferencyjne, (Kwiecień 2017)

8. A. De Virion, Wdrożenie systemu GIS w PEWiK Gdynia Sp. z o.o.- zastosowanie Bentley Open Utilities Designer, Geo Web Publisher firmy Bentley, Eksploatacja wodociagów $i$ kanalizacji - GIS modelowanie $i$ monitoring $w$ zarządzaniu syste-mami wodociagowymi $i$ kanalizacyjnymi, PZiTS/Zakład Zaopatrzenia $w$ Wodę $i$ Odprowadzania Ścieków Politechniki Warszawskiej, Materiały Konferencyjne, (Kwiecień 2017)

9. U.S.Shamsi, GIS applications for water distribution systems, Journal of Water Management Modeling R220, 21 (2004)

10. R.Ray, R.Tejada, D.Harrington, P.Hauffen, J.Edwards, E.Koval, B.Lendt, P.Ginther, A.Black, Integration in practice, Hydraulic modeling and GIS 4, 51 (2012)

11. P.L.Iglesias-Reya, F.J.Martinez-Solana, J.V.Ribelles-Aquilara, Extending EPANET capabilities wid Add-In tools, Procedia Engineering, 186 (2017)

12. U.M.Shamsi, GIS applications for water distribution systems, Journal of Water Management Modeling, https://www.chijournal.org/Journals/PDF/R220-21 (2004)

13. C.Grabarczyk, Hydraulika urządzeń wodociagowych, Tom I, II, Wydawnictwo NOT Warszawa (2015)

14. J.Izquierdo, Error analysis of some demand simplifications in hydraulic models of water supply networks, Abstract and Applied Analysis, 2013 (2013)

15. V.Kanakoudis, K.Gonelas, Accurate water demand spatial allocation for water networks modelling using a new approach, Urban Water Journal, 12 (2015)

16. ArcGIS Help, Exporting a geodatabase schema to an XML workspace document, http://desktop.arcgis.com/en/arcmap/10.3/manage-data/geodatabases/exporting-ageodatabase-schema-to-an-xml-workspace-document.htm (2016)

17. Description of ESRI2Epa program, ESRI Polska, (2017)

18. L.A. Rosman, EPANET 2 User's Manual, EPA/600/R-00/057, US Environmental Protection Agency, Cincinnati (2000) 